\begin{tabular}{l|l}
\hline SISTEMA \\
ELETRONICO \\
DE REVISTAS \\
SER I UfPR \\
unw.ser.ufpr.br
\end{tabular}

\title{
O vencedor leva tudo: a corrida chinesa por recursos e seu significado para o mundo
}

\author{
Winner Take All: China's Race for Resources and What it \\ Means for the World
}

\begin{abstract}
MOYO, Dambisa - O vencedor leva tudo: a corrida chinesa por recursos e seu significado para o mundo. Tradução Cássio de Arantes Leite. Rio de Janeiro: Objetiva, 2013. 255p. Traduzido do original Winner Take All (New York: Basic Books, 2012). ISBN 978-85-390-0480-5.
\end{abstract}

\begin{abstract}
Glauco Leonardo Evangelista GUIMARÃES ${ }^{1}$
${ }^{1}$ Engenheiro Mecânico (UFU). Mestrando em Desenvolvimento Sustentável pela Universidade de Brasília (UnB). E-mail: glaucoglauco@ gmail.com
\end{abstract}

Resenha: Recebida em: 2 de dezembro de 2013; Versão final aceita em: 21 de março de 2014.

Dambisa Moyo (1969), nascida na Zâmbia, é doutora em Economia pela Universidade de Oxford e fundadora do Mildstorm Group, empresa especializada em macroeconomia global, mercados financeiros mundiais e estratégias de investimento. Atua como diretora nos conselhos do grupo financeiro Barclay Bank, da cervejaria SABMiller e da multinacional mineradora Barrick Gold. Foi consultora do Banco Mundial e economista do Goldman Sachs, no qual trabalhou por quase dez anos. Este seu terceiro livro é precedido por duas obras bem conceituadas: Dead Aid: Why Aid is Not Working and How There is a Better Way for Africa (2009) e How The West Was Lost: Fifty Years of Economic Folly and the Stark Choices Ahead (2011). Ambas analisam as relações internacionais e as questões geopolíticas como determinantes da vulnerabilidade ou da supremacia econômica dos países. Neste livro, Moyo caminha pelo mesmo território e mostra como a China antevê um cenário futuro de intensa escassez de recursos no planeta, adotando estratégias políticas e econômicas que possam garantir a manutenção do suprimento de sua economia, uma das grandes engrenagens do capitalismo atual.

A autora discute os resultados de sua pesquisa como um alerta para todas as nações que não têm se preparado para o provável futuro de escassez global de recursos. Os seus estudos indicam que há apenas uma exceção, a China, que demonstra reconhecer o aumento da pressão da demanda mundial por água, terra arável e commodities diversas (açúcar, milho, cacau, café, petróleo, gás natural, minerais metálicos e não metálicos e outros), admitindo o risco do crescimento da instabilidade de todas as economias. Para demarcar este cenário, Moyo 
expõe um inventário detalhado da disponibilidade dos recursos disponíveis, contrapondo a tendência de redução de oferta ao potencial de crescimento da demanda pelas commodities. Aponta com precisão os dois principais fatores determinantes do aumento crítico dessa demanda: o crescimento populacional e o aumento dos padrões de vida, ambos em curso em todo o mundo, fundamentados pela trajetória de enriquecimento das nações.

Os dados apresentados revelam o panorama ameaçador da insuficiência da oferta de recursos frente à demanda crescente. Analistas estimam que, em 2025, mais de três bilhões de pessoas no mundo enfrentarão escassez de água. $\mathrm{Na}$ China, onde o suprimento atual de água é de 617 trilhões de litros, a demanda deve saltar para 800 trilhões de litros em menos de 20 anos. Com relação à terra, o país também vive situação preocupante, já que mais de $40 \%$ dela não apresenta qualidade suficiente para suportar plantios, em decorrência da desertificação, sem contar o fato de que mais de $15 \%$ da terra arável está contaminada por metais pesados e degradada pela erosão. Da mesma forma, não é otimista o cenário para a energia e os recursos minerais. Ainda que a oferta mundial de petróleo tenha acompanhado a demanda, crescendo de dois bilhões de barris por ano, na década de 1930, para 30 bilhões de barris por ano em 2010, a economia baseada na energia do petróleo torna-se cada vez mais vulnerável diante da previsão de queda acelerada da capacidade de abastecimento dos campos petrolíferos, já que a Agência Internacional de Energia (AIE) projeta um declínio de quase 50\% na produção mundial de petróleo convencional para 2020. Além disso, os riscos de ruptura da oferta de petróleo, gás e recursos minerais são cada vez mais altos, em função de instabilidades políticas em todo o mundo. As energias renováveis estão se desenvolvendo e ganhando espaço nos mercados, mas não há expectativas de que o mundo abandone a sua completa dependência das fontes tradicionais até 2030.

A vantagem da China na disputa global pelos recursos é justificada especialmente por sua riqueza, que permite a adoção de estratégias econômicas e investimentos de capital impossíveis para os outros países. Em 2012, as suas reservas em moeda estrangeira acumulavam mais de três trilhões de dólares. Entre 2005 e 2012, envolveu-se em mais de 350 investimentos estrangeiros diretos ava- liados em mais de 400 bilhões de dólares, grande parte dos quais em recursos naturais. Essa posição permite que a China seja um investidor mais atraente do que órgãos internacionais, como o Banco Mundial. A China empresta recursos a governos estrangeiros, financia projetos de infraestrutura e fecha acordos que poderão garantir a manutenção do fornecimento de commodities necessárias ao desenvolvimento de sua economia. Hoje, o país é o grande exportador para os Estados Unidos e maior credor do governo americano. É o maior parceiro comercial isolado da África e de países da América do Sul, como Brasil e Chile. Tem adquirido direitos sobre a produção de recursos no mundo todo, a exemplo de reservas de cobre no Peru, de poços petrolíferos no Afeganistão, Iraque, Nigéria e Venezuela, do setor de alumínio na Austrália, de carvão na Rússia e até de terra arável na África e na América do Sul. Ainda que outros países participem dessa corrida por recursos no mundo, não há ameaças sobre a posição de liderança da China, que atualmente detém força financeira incomparável.

O livro mostra ainda que a supremacia chinesa no avanço sobre os mercados de commodities decorre não apenas de sua riqueza, mas principalmente do contexto político interno que dá suporte às suas estratégias econômicas. Indivíduos, corporações e Estado Comunista estão comprometidos coordenadamente com a busca do desenvolvimento como o seu principal objetivo, capitaneados pelo governo do partido comunista chinês, que assume o papel central de indutor das atividades econômicas e da geração de lucro. O Estado é dono da maior parte das empresas de capital aberto e de 30 das principais multinacionais do país, que são beneficiadas com concessões do governo e empréstimos de bancos estatais a juros baixos, o que as coloca em vantagem competitiva com relação a empresas de outras nações. Além disso, a China tem sido acusada de pagar em excesso por ativos de commodities, muito além dos preços justos de mercado, tornando os ativos inatingíveis para os seus competidores e determinando novos preços de equilíbrio.

Para desenvolver o seu estudo, a autora utilizou a sua experiência de atuação no mercado e informações levantadas a partir de trabalhos realizados em mais de 60 países. O texto traz à tona uma questão mundial relevante, já que o iminente desequilíbrio entre a demanda e a oferta globais deve gerar, no mínimo, uma alta ge- 
neralizada de preços de commodities e outros recursos naturais, o que promoveria uma queda preocupante do padrão de vida global. Pode-se esperar, no entanto, que os efeitos ultrapassem essa fronteira, acentuando o surgimento de instabilidade política, conflitos e guerras globais. Moyo revela que, desde o início da década de 1990, houve pelo menos 18 conflitos globais violentos atribuíveis à dificuldade ou à falta de acesso aos recursos. Neste contexto, é expressiva a contribuição da obra para que se tenha uma visão privilegiada acerca das minúcias que determinam o enfrentamento da questão da escassez dos recursos naturais do planeta.

O livro apresenta informações detalhadas e dados precisos, além de propor reflexão interessante não apenas para os especialistas, mas para todo leitor que se interesse por uma visão mais completa acerca do verdadeiro processo de encarecimento ou esgotamento dos recursos e das questões geopolíticas a ele associadas. $\mathrm{O}$ foco do trabalho está posicionado na estratégia chinesa de corrida pelas commodities, mas ele permite também compreender melhor as diferentes formas com as quais os demais países se posicionam nesse cenário. Em $O$ vencedor leva tudo, fica evidente que o momento histórico é singular e que a finitude dos recursos naturais já não é mais uma questão teórica e distante da realidade. Moyo convence o leitor de que, no contexto econômico atual, um país já largou na frente e assumiu posição de comando. 